\title{
Deletion of Registration and Identification of the Motorized Vehicle in the Perspective of Human Rights
}

\author{
Risang Pujiyanto \\ Polytechnic of ATK Yogyakarta, Indonesia \\ E-mail : risang.pujiyanto@gmail.com \\ Sonny Taufan \\ Polytechnic of STMI Jakarta, Indonesia
}

\begin{abstract}
How to cite : Pujiyanto, Risang and Sonny Taufan."Deletion of Registration and Identification of the Motorized Vehicle in the Perspective of Human Rights". UNIFIKASI : Jurnal Ilmu Hukum. 7(1). 2020. 17-27. DOI : 10.25134/unifikasi.v7i1.2487

Submitted : 14-01-2020

Revised : 07-04-2020

Accepted : 16-04-2020
\end{abstract}

\begin{abstract}
This research aims to review and analyze the provisions on the deletion of registration and identification of motorized vehicles data for the owners of motorized vehicles who do not re-register at least 2 (two) years after the validity period of the motorized vehicle number is expired in the perspective of Human Rights and provide prescriptions on the provisions referred to. This research is normative research by using statute approach. The results of the study found that motorized vehicle ownership is a Human Rights which is included in the category of derogable rights. The deletion of motorized vehicle data is a limitation of Human Rights and is regulated in Act Number 22/2009 about Traffic and Road Transport. However, the aforementioned limitation has the potential to be incompatible with the purpose of the limitation as stipulated in the Constitution of the Republic of Indonesia. Reviewing the provisions of Article 74 paragraph (3) of Act No. 22/2009 and implementation of the national program of changed motorized vehicle ownership, needs to be prioritized, so that the objectives of the motorized vehicle registration provisions can be achieved and will ultimately increase revenue from motorized vehicle tax.
\end{abstract}

Keywords: Motorized Vehicle, Property Right, and Human Rights Limitation.

\section{Penghapusan Registrasi dan Identifikasi Kendaraan Bermotor dalam Perspektif Hak Asasi Manusia}

Abstrak : Penelitian ini bertujuan mengkaji dan menganalisis ketentuan penghapusan registrasi dan identifikasi kendaraan bermotor bagi pemilik kendaraan bermotor yang tidak melakukan registrasi ulang sekurang-kurangnya 2 (dua) tahun setelah habis masa berlaku Surat Tanda Nomor Kendaraan Bermotor dalam perspektif Hak Asasi Manusia dan memberikan preskripsi atas ketentuan dimaksud. Penelitian ini merupakan penelitian normatif dengan menggunakan pendekatan undang-undang. Hasil penelitian menemukan bahwa kepemilikan kendaraan bermotor merupakan Hak Asasi Manusia yang termasuk dalam kategori derogable rights. Penghapusan data kendaraan bermotor diatur dalam Undang-Undang Nomor 22 Tahun 2009 dan telah sesuai dengan ketentuan pembatasan Hak Asasi Manusia ditetapkan dalam suatu Undang-Undang, namun pembatasan dimaksud berpotensi tidak sesuai dengan tujuan pembatasan yaitu Ketertiban Umum. Peninjauan ulang ketentuan Pasal 74 ayat (3) Undang-Undang Nomor 22 Tahun 2009 dan penyelenggaraan program balik nama kendaraan bermotor secara nasional perlu diprioritaskan agar tujuan ketentuan registrasi kendaraan bermotor dapat tercapai dan pada akhirnya akan meningkatkan pendapatan dari pajak kendaraan bermotor.

Kata Kunci: Kendaraan Bermotor, Hak Asasi Manusia, dan Pembatasan Hak Asasi Manusia.

\section{INTRODUCTION}

Transportation provides important access to daily life, and this need will increase in accordance with the increasing population in Indonesia. As a mode of daily transportation, private motorized vehicles are currently the main choices for human because of their movement and flexibility. This can be seen from the number of motorcycle ownership which reached 137.7 million 
or a half of the population in Indonesia. ${ }^{1}$ In every increase of the number of private motorized vehicle ownership, there is actually a potential tax revenue, but this has not been offset by public compliance in paying motorized vehicle tax. The Traffic corp from the Indonesian National Police plans to apply nationally the rules for the deletion of identity on the Vehicle Number Certificate (STNK), for motorized vehicles that are in arrears for two consecutive years in taxes. ${ }^{2}$ Provisions on the deletion of motorized vehicle identity are contained in Act Number 22/2009 concerning Traffic and Road Transportation (UU LLAJ), but there are not many people who understand it. The Indonesian National Police in their socialization stated that the public asked a lot of questions and most of them were worried if their vehicles would be removed. ${ }^{3}$

UU LLAJ in article 74 section 2 determine that the registered motorized vehicles can be deleted from the register and identification list, as follows:

1. The motor vehicles are heavily damaged thereby cannot be operated; or

2. The motorized vehicle owner fails to get re-registration at least for 2 (two) months after the expired date of the vehicle registration certificate.

For motorized vehicles that have been deleted from the registration and identification list, then it cannot be registered anymore. Motorized vehicles are included in the category of registered movable objects because the law requires registration in connection with ownership of such objects. Article 64 section (1) and (2) UU LLAJ, establish that every new motorized vehicle, alteration on the identity of the motorized vehicle and the owner, extension of the motorized vehicle, and legalization of the motorized vehicle must be registered. As proof that the motorized vehicle has been registered, the owner is given a Vehicle Ownership Book (BPKB), a motorized vehicle certificate (STNK), and a Motorized Vehicle Number (TNKB). BPKB is valid as long as the ownership is not transferred, while the STNK and TNKB are valid for 5 (five) years, which they must be sought for legalization in every year. Deleting motorized vehicle data from the registration and identification list (Motorized Vehicle Data Deleting) will raise new legal problems, including in obscurity of the vehicle ownership status.

The 1945 Constitution of the Republic of Indonesia (Constitution) Article $28 \mathrm{H}$ paragraph (4) states that everyone has the right to their own private property and that can not be appropriated arbitrarily by whomsoever. The phrase "everyone" indicates the relevant provisions apply, both to citizens and foreigners, both to residents and non-residents. ${ }^{4}$ Human Rights norms place individuals as right holders and the state as duty holders, which have obligations in the form of ${ }^{5}$ :

1. The obligation to respect, refers to the obligation to avoid intervention by the state which will reduce its rights or obstruct the enjoyment of rights.

2. The obligation to protect, to demand positive state action to ensure that the third parties do not violate human rights.

\footnotetext{
${ }^{1}$ Tim VIVA. March $11^{\text {th }} .2019$. Jumlah Motor di Indonesia, Separuh Populasi Penduduknya.Available on website $\quad$ https://www.viva.co.id/otomotif/motor/1129068-jumlah-motor-di-indonesia-separuh-populasipenduduknya. Accessed on July $5^{\text {th }}, 2019$.

${ }^{2}$ Aditya Maulana. July $7^{\text {th }} .2019$. "Penghapusan Data Kendaraan jika STNK Mati 2 Tahun Berlaku Tahun Ini". Available on website: https://otomotif.kompas.com/read/2019/07/12/062200015/penghapusan-datakendaraan-jika-stnk-mati-2-tahun-berlaku-tahun-ini. Accessed on August $5^{\text {th }}, 2019$.

${ }^{3}$ Setyo Adi Nugroho. Oct $25^{\text {th }}$. 2018.Reaksi Masyarakat Terhadap Peraturan Penghapusan STNK. Available on website https://otomotif.kompas.com/read/2018/10/25/102200815/reaksi-masyarakat-terhadap-peraturanpenghapusan-stnk. Accessed on July $5^{\text {th }}, 2019$.

${ }^{4}$ Bagir Manan, 2009, Hukum Kewarganegaraan Indonesia Dalam UU No. 18 Tahun 2016. Yogyakarta : FH UII Press, p. 53.

${ }^{5}$ Abustan, 2017, "Relasi Lembaga Negara Dalam Perspektif Undang Undang Dasar Negara Republik Indonesia 1945”, Jurnal Unifikasi, Vol. 4, No.2, p. 62.
} 
3. The obligation to fulfill, refers to the state obligation to take legislative, administrative and judicial behavior, also the actions needed to ensure that the rights being considered are carried out as much as possible or accessible to everyone.

Respect, protection and fulfillment of human rights need to be supported by the government policy in implementing the basic norms contained in the Constitution. ${ }^{6}$ As stated in Article $28 \mathrm{I}$ paragraph (4) on the Constitution which states that protecting, promoting, upholding, and the full realization of human rights are responsibilities of the state, especially the government. Therefore, it becomes an important issue to further study and analyze the provisions on the Motorized Vehicle Data Deleting from a human right perspective. Based on the background as mentioned above, the following research questions are, First, how is the proportionality of human rights limitation in terms of the deletion of motor vehicle registration and data identification? Second, what is the prescription for deleting motor vehicle registration and data identification?

\section{RESEARCH METHODS}

This research is a normative legal research using statute approach. The statute approach was carried out by examining all Act and regulations relating to human rights and the provisions on the Motorized Vehicle Data Deleting. In this study the legal materials used were primary legal materials and secondary legal materials. Primary legal materials were in the form of the Constitution, the Civil Code (Burgerlijk Wetboek), Act Number 5/1960 Concerning Basic Regulations On Agrarian Principles, Act Number 39/1999 Concerning Human Rights and Act Number 22/2009 concerning Traffic and Road Transportation. While secondary legal material was in the form of scholarly work as well as from internet which supported and related to this research. Legal materials were prescriptively analyzed to produce arguments on the legal issues studied.

\section{RESULTS AND DISCUSSION}

\section{Proportionality of Human Rights Limitation in terms of the Deletion of Registration and Identification of Motorized Vehicles.}

Constitution prior to the amendment contained a limited number of human rights regulations and it was formulated briefly. Through the second amendment of the Constitution, human rights regulations undergo significant changes. Jimly Asshiddiqie stated that after the second amendment of the Constitution, human rights could be classified into 4 groups containing 37 provisions, namely ${ }^{7}$ : First, the group of provisions concerning civil rights as follows :

1. Everyone has the right to live, defend his life and lives;

2. Everyone has the right to be free from torture, treatment or other punishment which is cruel, inhumane and degrading human dignity;

3. Everyone has the right to be free from all forms of slavery;

4. Everyone is free to embrace religion and worship according to his religion;

5. Everyone has the right to be free to have beliefs, thoughts, and conscience;

6. Everyone has the right to be recognized as a person before the law;

7. Everyone has the right to equal treatment before the law and government;

8. Everyone has the right not to be prosecuted based on retroactive laws;

9. Everyone has the right to form a family and carry on descendants through a legal marriage;

10.Everyone has the right to citizenship status;

11.Everyone has the right to live in the territory of his country, leave, and return to his country;

\footnotetext{
${ }^{6}$ Andi Muhammad Asrun, 2016,"Hak Asasi Manusia Dalam Kerangka Cita Negara Hukum”. Jurnal Cita Hukum, Vol. 4, No.1, p. 137.

${ }^{7}$ Jimly Asshiddiqie, 2006, .Pengantar Ilmu Hukum Tata Negara Jilid II. Jakarta: Sekretariat Jenderal dan Kepaniteraan MKRI, p. 105 - 108.
} 
12.Everyone has the right to political asylum;

13.Everyone has the right to be free from all forms of discriminatory treatment and has the right to get legal protection from such discriminatory treatment.

Second, political, economic, social and cultural rights groups which include :

1. Every citizen has the right to associate, gather and express his opinion peacefully;

2. Every citizen has the right to vote and be elected in the framework of the people's representative institutions;

3. Every citizen can be appointed to occupy public positions;

4. Everyone has the right to obtain and choose legal and decent work for humanity;

5. Everyone has the right to work, get paid, and get proper treatment in equitable employment relations;

6. Everyone has the right to have personal property rights;

7. Every citizen has the right to social security needed to live properly and allow his development as a dignified human being;

8. Everyone has the right to communicate and obtain information;

9. Everyone has the right to obtain and choose education and teaching;

10.Everyone has the right to develop and benefit from science and technology, art and culture to improve the quality of life and welfare of humanity;

11.The state guarantees respect for cultural identity and the rights of local people in harmony with the development of the times and the level of civilization of nations;

12.The state recognizes every culture as part of national culture;

13.The state guarantees the independence of each population to embrace their respective religions, and to worship according to their beliefs.

Third, special rights and development rights groups such as :

1. Every citizen who has social problems, including those who are isolated and who live in remote environments, has the right to get special facilities and treatment to get the same opportunities.;

2. Women's rights are guaranteed and protected to get gender equality in national life;

3. Special rights attached to women due to their reproductive function are guaranteed and protected by law;

4. Every child has the right to love, care, and protection of parents, family, community and country for physical and mental growth and personal development;

5. Every citizen has the right to participate in management and enjoy the benefits derived from the management of natural resources;

6. Everyone has the right to a clean and healthy environment;

7. Temporary special policies, treatments or actions that are stipulated in valid laws and regulations intended to equalize the level of development of certain groups that have experienced discriminatory treatment with other groups in the community, and such special treatment is not included in the definition of discrimination.

Fourth, the group responsible for the state and responsible for humans, as follows :

1. Everyone must respect the human rights of others in the orderly life of the community, nation and state;

2. In exercising their rights and freedoms, every person is obliged to submit to the limitations set forth in the law with the sole purpose of ensuring the recognition and respect for the rights and freedoms of others and to fulfill the demands of justice in accordance with religious values, morality, and decency, security and public order in a democratic society;

3. The state is responsible for the protection, promotion, enforcement and fulfillment of human rights; 
4. To guarantee the implementation of human rights, an independent and impartial National Commission on Human Rights whose formation, composition and position is regulated by law.

Property rights, including motorized vehicle ownership, are among the human rights in the political, economic, social and cultural rights guaranteed in the Constitution. Property on Act Number 5/1960 concerning Basic Regulations on Agrarian Principles (UUPA) are hereditary, strongest and most fully fulfilled rights by people on land. While Article 570 on the Civil Code defines property rights as : "the right to savor the usefulness of a material freely, and to act free on that object with complete sovereignty, as long as it is not in harmony with the laws or general regulations established by a power that has the right to determine it, and does not interfere with the rights of others; all of which do not reduce the possibility of revoking these rights in the public interest based on the provisions of the law and with compensation payments".

Based on the provisions of the Civil Code (article 570) and the UUPA, it can be concluded that the elements of property rights are as follows :

1. The right to use objects freely.

The right to use objects freely has two meanings, can do any legal actions on an object and can do material actions. ${ }^{8}$

2. There are limitation on property rights.

Limitation on property rights can be done if the intended ownership violates the law, causing interference with the rights of others.

3. The possibility of revocation of ownership proprietary with compensation.

Revocation of ownership proprietary with compensation can be done by considering the existence of public interests, including the interests of the nation, the State also the common interests from the people.

Ownership of an object can be obtained through the handover (levering) which is interpreted as the handover of an object by the owner or in his name to another person, so this other person obtains ownership of the object. ${ }^{9}$ In summary, Usanti states how to obtain ownership of an object is as listed in table $1 .^{10}$

Table 1. How to Get Ownership

\begin{tabular}{|l|l|l|}
\hline 1 & $\begin{array}{l}\text { Tangible moving } \\
\text { objects }\end{array}$ & $\begin{array}{l}\text { Article 612 paragraph 1 BW is carried out by real handover or hand-to- } \\
\text { hand handover. }\end{array}$ \\
\hline 2 & $\begin{array}{l}\text { Intangible } \\
\text { moving objects }\end{array}$ & $\begin{array}{l}\text { i. handover of account receivable on bearer (aan toonder) regulated in } \\
\text { Article } 613 \text { paragraph } 3 \mathrm{BW} \text { is carried out by real handover for } \\
\text { example: paper money } \\
\text { ii. handover of account receivable on name (vordering op naam) regulated } \\
\text { in Article } 613 \text { paragraph 1 BW is carried out by making an authentic } \\
\text { deed or private deed (cessie). } \\
\text { iii. handover of account receivable to those who order (aan order) } \\
\text { regulated in Article } 613 \text { paragraph } 3 \mathrm{BW} \text { is carried out by real handover } \\
\text { and accompanied by write it behind the receivables that state who the } \\
\text { receivables were transferred to (endossemen), example bill, check. }\end{array}$ \\
\hline 3 & Ownership & \begin{tabular}{l} 
Since the time of transfering ownership, (the signing of the sale and \\
\hline
\end{tabular}
\end{tabular}

\footnotetext{
${ }^{8}$ Sri Soedewi Masjchoen Sofwan, 2004, Hukum Perdata : Hukum Benda. Yogyakarta : Liberty, p. 42.

${ }^{9}$ Ibid, p. 67.

${ }^{10}$ Trisadini PrasastinahUsanti, 2012, “Lahirnya Hak Kebendaan”.Jurnal Perspektif, Vol. XVII, No.1, p. 52.
} 


\begin{tabular}{|l|l|l|l|}
\hline & $\begin{array}{l}\text { immovable } \\
\text { object (land } \\
\text { ownership rights) }\end{array}$ & purchase deed before the Land Deed Official). \\
\hline 4 & $\begin{array}{l}\text { Mastership } \\
\text { (Bezit) of moving } \\
\text { objects }\end{array}$ & $\begin{array}{l}\text { Real mastery in good faith then get protection from Article 1977 } \\
\text { paragraph 1 BW }\end{array}$ & $\begin{array}{l}\text { Mastership } \\
\text { (Bezit) } \\
\text { immovable of } \\
\text { object (property } \\
\text { rights) }\end{array}$ \\
\hline
\end{tabular}

Motorized vehicles are included in the list of registered movable objects, so that it requires registration, it is not enough only to do with the real handover. The purpose of registration is to provide legal certainty about a person's right in an object, then provide certainty about the right granting to the right holder. ${ }^{11}$ Motorized vehicles that have been registered, can be removed from the registration list and identification of motor vehicles, among others, by reason of the owner has not reregistered for at least 2 (two) years after the STNK validity period has expired. According to the Head of the Republic of Indonesia National Police Regulation Number 5/2012 about Registration and Identification of Motorized Vehicles, it is stated that the procedure on the Motorized Vehicle Data Deleting for motorized vehicle owners who have not authorized the vehicle for two years since the end of the STNK validity period is as follows :

1. 3 (three) months prior to the expiration of 2 (two) years, the first warning letter will be given for 1 (one) month after receiving the warning letter to register and identify the extension.

2. If the owner of a motorized vehicle ignore to the first warning, a second warning letter is given for 1 (one) month after.

3. If the motorized vehicle owner does not provide an answer to the second warning, then a third warning letter is given within one month of receiving the third warning carrying out the registration of the motor vehicle and it will be placed in the list of temporary deletions.

4. The deletion will be done by giving notes or stamp marks "DELETED" on the Master Card and Register Book on the Registration and Identification of Motorized Vehicle Ownership and Operation of the Motorized Vehicle, on the computer database, as well as on the physical BPKB and STNK of the Motorized Vehicle that is deleted.

Motorized Vehicle Data Deleting will eliminate the legitimacy of ownership of a motorized vehicle and thereby eliminate someone's ownership of a motorized vehicle. This is in accordance with Article 1 number 8 of the Regulations of the National Police Number 5/2012, which states that BPKB is a document that gives legitimacy to motor vehicle ownership issued by the National Police and contains the identity and owner, which is valid as long as the motorized vehicle is not transferred. Every person in principle has the property rights and these property rights may not be taken arbitrarily by anyone. Provisions aforementioned contained in Article 28 paragraph (4) of the Constitution and Article 36 paragraph (1) and (2) of Act Number 39/1999 Concerning Human Rights.

In principle human rights cannot be reduced, but in the repertoire of human rights law there are known derogable rights, human rights that may be reduced or limited to fulfillment which include the

\footnotetext{
${ }^{11}$ Elisabeth NurhainiButarbutar, 2012, Hukum Harta Kekayaan Menurut Sistematika KUH Perdata dan Perkembangannya. Bandung : Refika Aditama, p. 34.
} 
right to freedom of opinion or expression, the right to freedom of assembly peacefully, and the right to freedom of association. ${ }^{12}$ Meanwhile human rights that cannot be reduced, or known as nonderogable rights are regulated in Article 28 I paragraph (1) of the Constitution which reads:

"The rights to live, to remain free from torture, to freedom of thought and conscience, to adhere in the religion, the right to un-enslaved, to be treated as an individual before the law, and the right not to be prosecuted on the basis of retroactive legislation, are fundamental human rights that shall not be curtailed under any circumstance."

The other Human rights besides contained in Article 28 I paragraph (1) of the Constitution are included in the category of derogable rights, thus the state may limit its implementation. ${ }^{13}$ The limits on the implementation of human rights are stipulated in Article $28 \mathrm{~J}$ paragraph (2) of the Constitution as follows: "In exercising his rights and liberties, each person has the duty to accept the limitations determined by law for the sole purposes of guaranteeing the recognition and respect of the rights and liberties of other people and of satisfying a democratic society's just demands based on considerations of morality, religious values, security, and public order."

Article $28 \mathrm{~J}$ paragraph (2) of the Constitution contains 2 (two) aspects, first, a limitation must be determined by Act, second, the limitation is intended to guarantee recognition and respect for the rights and liberties of others people, moral considerations, religious values, security and public order. ${ }^{14}$ Meanwhile, Article 37 paragraph (1) of Act Number 39/1999 determines that property rights can be revoked for public interest and by compensating for reasonable damage.

Human rights limitation must be based on substantive reasons as regulated in Article $28 \mathrm{~J}$ paragraph (2) of the Constitution. The state in limiting human rights must not reduce its essence which is beneficial for the holder or owner of human rights. ${ }^{15}$ Proportionality in limiting human rights needs to do to ensure that derogable rights are not reduced arbitrarily. Thus, in implementing the provisions on the Motorized Vehicle Data Deleting, human rights limitation must be appropriate with the provisions 1) "Human rights limitation are determined by the Act", and 2) "legitimate purposes, relating to the legitimate purpose on human rights limitation". The limitation set by the Act means that the only legal basis for limiting human rights is only the Act (legislation) not other legal products (regulation). ${ }^{16}$ This is partly related to the existence of a hierarchy of laws and regulations, where the Constitution functions as a basic law and is at the top of the pyramid while other provisions are under the constitution. Provisions on human rights limitation in the form of the Motorized Vehicle Data Deleting have been regulated in Article 74 paragraph (2) of UU LLAJ, thus the limitation referred to are in accordance with the principle of human rights limitation stipulated by Act. The Act made as a legislative product is a legitimate limitation of human right.

The second principle, based on "legitimate purpose", which according to Article $28 \mathrm{~J}$ paragraph (2) of the Constitution is to guarantee the recognition and respect on the other people's rights and liberties and to satisfy a democratic society's based on considerations of morality, religious values, security, and public order. In connection with the purpose of property rights limitation, the Constitutional Court in decision Number 11 / PUU-V / 2007 argue that:

"Constitutional rights consisting of human rights contained in Article 28A to Article 28J of the 1945 Constitution and other rights of citizens listed in the 1945 Constitution including property rights on

\footnotetext{
${ }^{12}$ Yuli AsmaraTriputra, 2017, "Implementasi Nilai-Nilai Hak Asasi Manusia Global ke dalam Sistem Hukum Indonesia yang Berlandaskan Pancasila”.Jurnal Hukum IUS QUIA IUSTUM, Vol. 24, No. 2, p. 285.

${ }^{13}$ Suparman Marzuki, 2013, "Perspektif Mahkamah Konstitusi Tentang Hak Asasi Manusia".Jurnal Yudisial, Vol. 6, No. 3, p. 197.

${ }^{14}$ Opcit, p. 40-41.

${ }^{15}$ Titon SlametKurnia, 2015, Interpretasi Hak-Hak Asasi Manusia Oleh Mahkamah Konstitusi Republik Indonesia. Bandung : Mandar Maju, p. 324.

${ }^{16}$ Galuh Chandra Purnamasari, 2017, "Problematika Penerapan Aturan Pembatasan Hak Asasi Manusia Dalam Konstitusi Indonesia”.Jurnal Hukum Prioris, Vol.16, No. 2, p. 194.
} 
property (assets). Property rights on land which are a very strong right (hereditary) as determined in the UUPA can be limited, in accordance with the provisions in Article 28J Paragraph (2) of the 1945 Constitution. The limitation as regulated in Act 56/1960 is a maximum of 20 hectares of agricultural land. This does not contradict the 1945 Constitution. Moreover, as described above, land and ownership rights are social functions. The purpose of Act 56/1960 is in the context of restructuring land ownership (landreform) so the social function of land can be truly realized as the implementation or manifestation on Article 33 Paragraph (3) of the 1945 Constitution, namely land controlled by the state and used for the greatest extent prosperity of the people."

Based on the decision of the Constitutional Court No. 11 / PUU-V / 2007, it can be seen that the Constitutional Court in determining its legitimate purpose based on the provisions of Article 28J Paragraph (2) of the 1945 Constitution, also based on the purpose of limiting land rights, namely the restructuring of land ownership ( landreform) so the social function of the land can be realized.

Thus to determine the legitimate purpose in limiting property rights, in casu motor vehicles ownership, it is necessary to review the provisions contained in the UU LLAJ. Article 4 of the UU LLAJ states that the UU LLAJ shall be valid to nurture and organize the secure, safe, orderly and smooth Road Traffic and Transportation through:

a. the Vehicle moving activities, person and/or goods on the Road;

b. the activity by using the facility, infrastructure and supporting facility of the Traffic and Road Transportation; and

c. the activity relating to the registration and identification of the Vehicle also the Driver, education on doing the traffic, Traffic Management and Engineering, as well as the law enforcement of Traffic and Road Transportation.

Such as the provisions on Article 4 of the UU LLAJ, the reason for public order is the legitimate purpose that comes closest to limiting property rights in accordance in Article 28J Paragraph (2) of the Constitution. The Regulation of Home Affairs Minister Number 44 of 2010 as regards Peace, Order and Community Protection in the Framework of Upholding Human Rights defines serene and public order as a dynamic condition that enables the government, regional government and the public to carry out their activities in a serene, orderly and orderly manner. Public order is related to a condition that allows the community to actively carry out community life, and the government can carry out government work well. Motorized Vehicle Data Deleting will potentially cause new problems, such as the legality of ownership of motorized vehicles, whether motorized vehicles that are pledged as collateral or fiduciary are still valid or not, how the mobility of the community in daily life after personal motorized vehicle data is deleted and so on. The practice of the Motorized Vehicle Data Deleting will raise chaos, so it is unlikely to create public order in people's lives. Thus the application of the Motorized Vehicle Data Deleting will not in accordance with the purpose of carrying out human rights limitation as regulated in Article $28 \mathrm{~J}$ paragraph (2) of the Constitution. Provisions of Act that violate the constitutional rights of citizens can be brought to the Constitutional Court as a case for judicial review. By remembering that the regulation of human rights in the Constitution in addition to asserting human rights as fundamental rights, also asserted human rights as the supreme constitutional rights, the highest constitutional rights. ${ }^{17}$

\section{Prescription of Deletion of Vehicle Registration and Identification Data.}

The limitation on human rights is possible by the Constitution, but these must not be in arbitrarily. Before implementing the provisions on the Deletion of Vehicle Registration, the government must at least use the principle of necessity, weighing in advance whether the human

\footnotetext{
${ }^{17}$ Bagir Manan and Susi Dwi Harijanti, 2016. "Konstitusi dan Hak Asasi Manusia". Jurnal Ilmu Hukum, Vol. 3, No. 3, p. 465
} 
rights limitation measures are indeed necessary in order to achieve the objectives, and whether there are no other alternatives available and can be done to achieve the goals without limiting the protected interests. ${ }^{18}$ In connection with the Deletion of Vehicle Registration, actually there are 2 (two) alternatives available so that the objectives of the UU LLAJ provisions can be achieved, namely 1) reviewing the provisions on the Deletion of Vehicle Registration specifically the UU LLAJ on Article 74 paragraph (3) and 2) organizing a program to transfer the ownership name of a motorized vehicle nationally. UU LLAJ on Article 74 paragraph (3) states that motorized vehicles that have been deleted from the registration and identification list cannot be re-registered. This provision negates the efforts of the community to correct their mistakes. In a state of law, the law embodied in the Act is made as an instrument in managing the life of the state, government and society which is based on justice, peace and benefit. ${ }^{19}$ Justice is one of the most important goals of law, in addition to legal certainty, usefulness and order. ${ }^{20}$ To create social justice, citizens must have a balance between rights and the implementation of obligations. ${ }^{21}$ Reviewing the provisions of the UU LLAJ Article 74 paragraph (3) should be carried out by legislators. The temporary Motorized Vehicle Data Deleting, and / or re-registration of motor vehicles after the public has paid tax arrears, needs to be considered as a new provision. The alternative provisions referred to can provide a second chance to the negligent community in fulfilling their obligations. Compliance with the community in fulfilling the obligation to pay motorized vehicle tax cannot be short, but in stages. The law is used as a driving instrument to achieve the goals that have been set, although sometimes achieving these goals requires no short time. ${ }^{22}$

The national program of changed motorized vehicle ownership is the second alternative before enacting Motorized Vehicle Data Deleting provisions. The provision on Article 70 paragraph (1) of the UULAJ states that BPKB is valid as long as its ownership is not transferable, but in practice, there are still many people who own motorized vehicles, especially used vehicles, without changing ownership name. Through the national program of changed motorized vehicle ownership, more than one motorized vehicle ownership can be taxed at a progressive rate. This policy program is supported by the existence of a Single Identity Number (NIK) which is single and attached to someone who was registered as a resident of Indonesia. Article 64 paragraph (2) on Act Number 24/2013 concerning Amendment to Act Number 23/2006 concerning Population Administration confirms that NIK is the single identity number for all matters of public service matters which include the issuance of a driving license, business license, taxpayer services, banking services, land certificate issuance services, insurance, public health insurance, and / or labor social security. The tax on motorized vehicles can be used as a policy instrument to encourage development, in addition to that an orderly and integrated motorized vehicle administration will be realized.

\section{CONCLUSION}

Based on the results of the research and discussion described in the previous chapter, it can be concluded that first, the Motorized Vehicle Data Deleting is one of the acts of limiting human rights which is included in the category of derogable rights. Based on the provisions of "human rights limitation established by Act", it can be seen that the Motorized Vehicle Data Deleting is regulated in the UU LLAJ and is in accordance with the provisions of human rights limitation. Meanwhile, with

\footnotetext{
${ }^{18}$ M. Luthfi Chakim, 2018, "Prinsip Proporsionalitas". Majalah Konstitusi, p. 139 : 78.

${ }^{19}$ Ridwan, HR, 2017, Hukum Administrasi Negara. Jakarta : RajaGrafindo Persada, p. 22.

${ }^{20}$ Indriati Amarini, 2018, "Mewujudkan Keadilan Sosial dalam Penyelesaian Sengketa Di Pengadilan Administrasi". Jurnal Media Hukum, Vol. 25, No. 2, p.164.

${ }^{21}$ Yunie Herawati, 2014,"Konsep Keadilan Sosial Dalam Bingkai Sila Kelima Pancasila”.Jurnal Paradigma, Vol. 18, No.1, p.25.

${ }^{22}$ Satjipto Rahardjo, 2012, .Ilmu Hukum. Bandung : Citra Aditya Bakti, p. 219.
} 
regard to the purpose of limiting human rights, it can be seen that the Motorized Vehicle Data Deleting is not in accordance with the purpose of limiting human rights. The Motorized Vehicle Data Deleting has the potential to cause chaos in the community.

There are 2 (two) alternative actions that can be taken by the government before enacting the provisions on the Motorized Vehicle Data Deleting, namely 1) reviewing the provisions of the UU LLAJ Article 74 paragraph (3) and 2) organizing of the national program of changed motorized vehicle ownership. A review of the provisions needs to be done to provide a second chance to the negligent community in fulfilling their obligations. The implementation of the transfer program is supported by the existence of a single NIK in accordance with the Act Number 24/2013, can realize the orderly administration of motor vehicles, and in the end will increase revenue from the tax sector.

\section{SUGGESTION}

Based on the conclusions above, the authors suggest that the government weigh the pros and cons of implementing the Motorized Vehicle Data Deleting provisions, so that they do not become a new problem. Reviewing the provisions of the UU LLAJ Article 74 paragraph (3) and the national program of changed motorized vehicle ownership, need to be a priority of the government.

\section{REFERENCES}

\section{Books}

HR, Ridwan. Hukum Administrasi Negara.Jakarta :RajaGrafindo Persada.2015.

Kurnia, Titon Slamet. Interpretasi Hak-Hak Asasi Manusia Oleh Mahkamah Konstitusi Republik Indonesia.Bandung : Mandar Maju. 2015.

Manan, Bagir. Hukum Kewarganegaraan Indonesia Dalam UU No. 18 Tahun 2016. Yogyakarta : FH UII Press. 2009.

NurhainiButarbutar, Elisabeth. Hukum Harta Kekayaan Menurut Sistematika KUH Perdata dan Perkembangannya. Bandung : Refika Aditama. 2012.

Rahardjo, Satjipto. Ilmu Hukum.Bandung : Citra Aditya Bakti. 2012.

Sofwan, Sri Soedewi Masjchoen. Hukum Perdata : Hukum Benda. Yogyakarta : Liberty. 2004.

\section{Journal articles}

Abustan. "Relasi Lembaga Negara Dalam Perspektif Undang Undang Dasar Negara Republik Indonesia 1945”, Jurnal Unifikasi, Vol. 4, No.2, Juli 2017. p. 62. DOI : https://doi.org/10.25134/unifikasi.v4i2.693

Amarini, Indriati. "Mewujudkan Keadilan Sosial dalam Penyelesaian Sengketa Di Pengadilan Administrasi". Jurnal Media Hukum, Vol. 25, No.2, Desember 2018, p.164. DOI:10.18196/jmh.2018.0111

Asrun, Andi Muhammad. "Hak Asasi Manusia Dalam Kerangka Cita Negara Hukum". Jurnal Cita Hukum, Vol. 4, No. 1, Juni 2016, p. 137. DOI :10.15408/jch.v4i1.3200

Herawati, Yunie. "Konsep Keadilan Sosial Dalam Bingkai Sila Kelima Pancasila". Jurnal Paradigma, Vol. 18, No. 1, Januari 2014, p. 25 : http://jurnal.upnyk.ac.id/index.php/paradigma/article/download/2404/2042

Manan, Bagir and Dwi Harijanti, Susi. "Konstitusi dan Hak Asasi Manusia". Jurnal Ilmu Hukum, Vol. 3, No. 3, 2016, p. 465. DOI : https://doi.org/10.22304/pjih.v3.n3.a1

Marzuki, Suparman. "Perspektif Mahkamah Konstitusi Tentang Hak Asasi Manusia". Jurnal Yudisial, Vol. 6, No. 3, Desember 2013, p. 197. DOI :http://dx.doi.org/10.29123/jy.v6i3.98

Purnamasari, Galuh Chandra. "Problematika Penerapan Aturan Pembatasan Hak Asasi Manusia Dalam Konstitusi Indonesia”. Jurnal Hukum Prioris, Vol. 16, No. 2, 2017, p. 194. DOI : https://www.trijurnal.lemlit.trisakti.ac.id/prioris/article/view/2439/2063 
Triputra, Yuli Asmara. "Implementasi Nilai-Nilai Hak Asasi Manusia Global ke dalam Sistem Hukum Indonesia yang Berlandaskan Pancasila”. Jurnal Hukum IUS QUIA IUSTUM, Vol, 24, No. 2, April 2017, p.285. DOI :https://doi.org/10.20885/iustum.vol24.iss2.art6

Usanti, Trisadini Prasastinah. "Lahirnya Hak Kebendaan". Jurnal Perspektif, Vol. XVII , No. 1, Januari 2012, p.52. DOI : http://dx.doi.org/10.30742/perspektif.v17i1.93

\section{Articles}

Asshiddiqie, Jimly. 2006. Pengantar Ilmu Hukum Tata Negara Jilid II. Jakarta: Sekretariat Jenderal dan Kepaniteraan MKRI. Available on website http://mitrahukum.org/wpcontent/uploads/2012/09/Pengantar_Ilmu_Hukum_Tata_Negara_Jilid2.pdf.pdf.

Chakim, M. Luthfi. 2018. "Prinsip Proporsionalitas". Majalah Konstitusi, 139, 78, Available on website

https://mkri.id/public/content/infoumum/majalahkonstitusi/pdf/Majalah_144_1.\%20Edisi\%20

September\%202018\%20.pdf

\section{Regulations}

The Constitution of the Republic of Indonesia of 1945.

Act Number 5/1960 Concerning Basic Regulations On Agrarian Principles.

Act Number 39/1999 Concerning Human Rights.

Act Number 22/2009 concerning Traffic and Road Transportation.

Act Number 24/2013 concerning Amendment to Act No. 23/2006 concerning Population Administration.

Regulation of the Head of the Republic of Indonesia National Police Number 5/2012 Regarding Registration and Identification of Motorized Vehicles.

\section{World Wide Web}

Maulana, Aditya. July 7 $7^{\text {th }}$. 2019. "Penghapusan Data Kendaraan jika STNK Mati 2 Tahun Berlaku Tahun Ini”. Available on website: https://otomotif.kompas.com/read/2019/07/12/062200015/penghapusan-data-kendaraan-jikastnk-mati-2-tahun-berlaku-tahun-ini. Accessed on August $5^{\text {th }}, 2019$.

Nugroho, Setyo Adi. Oct 25 ${ }^{\text {th }}$ 2018.Reaksi Masyarakat Terhadap Peraturan Penghapusan STNK. Available on website https://otomotif.kompas.com/read/2018/10/25/102200815/reaksimasyarakat-terhadap-peraturan-penghapusan-stnk. Accessed on July $5^{\text {th }}, 2019$.

VIVA, Tim. March 11 ${ }^{\text {th }}$. 2019. Jumlah Motor di Indonesia, Separuh Populasi Penduduknya.Available on website https://www.viva.co.id/otomotif/motor/1129068-jumlahmotor-di-indonesia-separuh-populasi-penduduknya. Accessed on July $5^{\text {th }}, 2019$. 